\title{
SERIES-SERIES AND SERIES-PARALLEL COMPENSATION TOPOLOGIES FOR DYNAMIC WIRELESS CHARGING
}

\author{
MuHAmMad Amirul Asyraf Roslan, NAdia NazieHa NANDA* \\ AND SITI HAJAR YUSOFF \\ Department of Electrical and Computer Engineering, \\ Kulliyyah of Engineering, International Islamic University Malaysia, \\ Jalan Gombak, 53100 Kuala Lumpur, Malaysia \\ *Corresponding author: nnazieha.nanda@gmail.com
}

(Received: $16^{\text {th }}$ October 2020; Accepted: $2^{\text {nd }}$ February 2021; Published on-line: $4^{\text {th }}$ July 2021)

\begin{abstract}
Electric vehicles (EV) have gained worldwide attention since the implementation of a wireless power transfer (WPT) to charge their batteries. With WPT, it can be very convenient for EV to be charged dynamically. Nevertheless, there are some issues in dynamic WPT, such as maintaining the power transfer efficiency. Several factors that lead to these problems include disruption of the alignment and the optimum distance between the transmitter and receiver coils. It is thus contributing to the loss of power efficiency when charging the EV. Not to mention, manufacturers build different specifications of EV charging station for different types of EV models in order to meet customer demands. An incompatible charging device will not utilize EV wireless charging to its maximum potential. Hence, to improve the power output capability as well as stabilizing the maximum power transfer during the charging process, a compensation circuit is added to the system. This article focuses on comparing two available compensation circuits (series-series (SS) topology and series-parallel (SP) topology) under the application of dynamic wireless charging. The simulations are conducted using NI Multisim based on the relationship of power transfer efficiency with resonance frequency, coefficient of coupling, and the load resistance. The WPT efficiency for SP-topology shows that it is sensitive to the change of resonance frequency and coupling coefficient, whereas SS-topology maintains good efficiency during the WPT process. Nonetheless, SS-topology performance suffers efficiency loss when paired with a higher load, while SP-topology acts differently. This article will observe the best conditions on the selected compensation designs for better application in EV charging systems in a moving state.
\end{abstract}

ABSTRAK: Kenderaan elektrik (EV) telah menarik perhatian dunia sejak pelaksanaan alih kuasa wayarles (WPT) bagi mengecas bateri. Melalui WPT, EV lebih mudah kerana ia boleh dicas secara dinamik. Namun, pengecasan dinamik WPT turut mengalami masalah, seperti mengimbang kecekapan pemindahan kuasa. Beberapa faktor yang membawa kepada masalah ini adalah kerana terdapat gangguan penjajaran dan jarak optimum antara gegelung pemancar dan penerima. Kerana ini, ia menyumbang kepada kehilangan kecekapan kuasa semasa mengecas EV. Pengeluar juga membina spesifikasi stesen pengisian EV berlainan mengikut jenis model EV demi memenuhi permintaan pelanggan. Namun, platform pengecas EV yang berbeza, tidak dapat mengecas EV secara wayarles dengan maksimum. Oleh itu, bagi membaiki keupayaan jana kuasa serta menstabilkan pengeluaran kuasa maksimum semasa proses pengecasan, litar gantian ditambah ke dalam sistem. Artikel ini memberi keutamaan pada dua litar gantian berbeza (topologi bersiri (SS) dan siri-selari (SP)) di bawah aplikasi pengecasan wayarles dinamik. Simulasi dibuat menggunakan NI Multisim mengikut kecekapan pemindahan kuasa dengan frekuensi resonan, pekali gandingan dan rintangan beban. Kecekapan WPT bagi topologi-SP 
menunjukkan ianya sensitif pada perubahan frekuensi resonan dan pekali gandingan. Manakala topologi-SS kekal cekap semasa proses WPT. Walau bagaimanapun, prestasi topologi-SS berkurangan ketika diganding dengan beban besar, begitu juga berbeza bagi topologi-SP. Artikel ini akan mengkaji keadaan terbaik pada reka bentuk gantian terpilih bagi aplikasi EV dalam sistem pengecasan bergerak.

KEYWORDS: electric vehicle (EV); wireless power transfer (WPT); dynamic charging compensation topology; capacitor arrangement

\section{INTRODUCTION}

The first electric vehicle (EV) introduction was more than 100 years ago. The invention started from a battery and gradually evolved to an electric motor. In the early $19^{\text {th }}$ century, technology pioneers demonstrated a battery-powered conceptualization vehicle. A British inventor, Robert Anderson built the first-ever a simple electric carriage. In the 1890s, a chemist named William Morrison successfully developed an electric car with a top speed of 14 miles per hour [1]. In the automotive industry, conventional vehicles can be manufactured easily and more affordably for consumers. Still, they present some inconveniences such as being a bit noisy and emitting unpleasant pollutants from their exhaust systems.

In comparison to a conventional vehicle, EV shows significant advantage in terms of noise, and environmental friendliness. Not to mention that EV is a current solution for the concern of environmental pollution, and depletion of energy resources as well as the increased cost for petroleum [1,2]. EV uses electricity as its propulsion, so the main component to store the electricity is the lithium-ion battery. The lithium-ion battery has a shallow discharge rate; its implementation increases the energy stored as well as increasing the travel distances of an EV [3].

The application of wireless charging in EV brings more convenience to its consumer. The ability to charge without any contact reduces the hassle faced by consumers. It increases consumer's safety, is spark-free, has fewer maintenance requirements, provides more reliability, and the charging method is not affected by its surroundings [4]. WPT uses the electromagnetism theory, where energy can be transferred using inductive coupling or capacitive coupling. For the capacitive coupling, the electric fields are used to transfer power between two plates. For inductive coupling, the energy is transmitted between the coils of the receiver and the transmitter via the magnetic field [5]. Ampere's law and Faraday's law are two principles behind the operation of inductive power transfer (IPT).

Figure 1 displays an illustration of the WPT system for EV. The main components that contribute to wireless power transfer are the transmitting coil and the receiving coil [6]. The power is transferred through the air from the coil at the charging pad to the coil installed in the EV. There are also other significant components for EV, which include both the transmitting side and the receiving side. At the transmitter, there is a voltage source, an AC/DC converter, a compensation circuit, and a transmitter coil. While at the receiver side, there is a receiver coil, a compensation circuit, AC/DC converter, and battery storage. The grid will supply power in terms of alternating current (AC). The AC/DC converter will convert it into DC and again convert it to AC as the concept needed to transfer wireless energy needs it to be AC current passing through the coils thus, the WPT phenomenon occurs. Then, at the receiver side, the AC will be converted into DC so it can be stored into the battery bank $[7,8]$. 
Through this implementation, EV can be charged in two states, either static or dynamic. Static wireless charging (SWC) is a charging process where the vehicle is idle such as when it is parked in a mall or garage. Dynamic wireless charging (DWC) is a charging process that takes places while the vehicle is moving on the road. However, the combination of both SWC and DWC is known as Quasi-dynamic Wireless Charging (QWC) [9]. As the EV is in state of motion, the power transfer efficiency is varied due to the inconsistency of airgap distances as well as the misalignment between the transmitter coil and the receiver coil. This situation will cause a low magnetic flux density. It is known that flux density is directly proportional to induced current. Low magnetic flux results in a loss of power efficiency due to of low magnetic flux density [10].

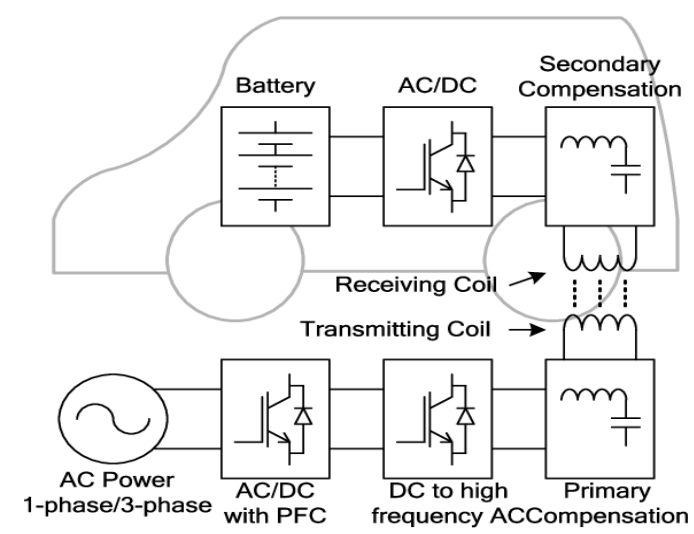

Fig. 1: WPT main components in EV [8].

A compensation circuit can compensate for the power transfer loss. It ensures that the output power for the WPT is maintained at a fixed level across wide variations in coupling [5]. There are four basic compensation designs: Series-Series (SS) topology, Series-Parallel (SP) topology, Parallel-Series (PS) topology, and Parallel-Parallel (PP) topology. Throughout this article, only two compensation circuits are chosen: Series-Series (SS) topology and Series-Parallel (SP) topology. SS-topology and SP-topology are more economically suitable for high power transmission [11]. These two topologies are further studied in finding which compensation designs performed well under DWC in terms of maximum power transfer capability and power transfer efficiency.

The author of [10] used the approach of applying mutual coupling for a different set of compensation designs (SS-topology and SP-topology) to analyse which topology can work well during the charging of an EV battery at constant voltage and constant current. SStopology resulted in both situations of possible constant voltage or constant current, making it suitable for maintaining the charging process as the position of the primary system is changing with respect to the secondary system, such as an in-motion charging situation. Same value of parameters was used in [13] research, where it focused on transferring the resonant frequency equally to the operating frequency of the power source. Between SStopology and SP-topology, a larger transmission range can be achieved with the series design in the secondary side. Parallel design, however, is capable of transferring higher output with a drastic load attached. In addition, the author in [15] carried out the test by setting up different compensation designs (SS-topology and SP-topology) using a mutual inductance model at resonance state. Despite that, SS-topology exhibited 70\% of maximum efficiency while SP-topology achieved 66\%. 


\section{ANALYSIS OF SS-TOPOLOGY AND SP-TOPOLOGY}

With the absence of the compensation circuit in the WPT system, the power transfer efficiency is inefficient compared to a circuit with compensation technology [12]. The inductance leakage in the WPT system causes low power efficiency. Therefore, an additional capacitor is placed either in series or parallel at both the transmitter and receiver side to compensate for the leakage. The capacitive compensation not only solves the inductance leakage but also improves mutual coupling of the primary and secondary coils [13]. Figures 2 and 3 show the schematic circuit diagrams for both SS-topology and SPtopology. $V_{I}, C_{1}$ and $L_{1}$ denote the supply voltage, primary capacitance, and primary inductance at the transmitter side of the circuit. $C_{2}, L_{2}$ and $R_{L}$ denote the secondary capacitance, secondary inductance, and the load resistance at the receiver side of the circuit. The $M$ represents the mutual inductances in this circuit. For the ideal case, the $\mathrm{R}_{1}$ and $\mathrm{R}_{2}$ are neglected $\left(R_{1}+R_{2}=0\right)$ so that the circuit operates without the presence of disturbances.

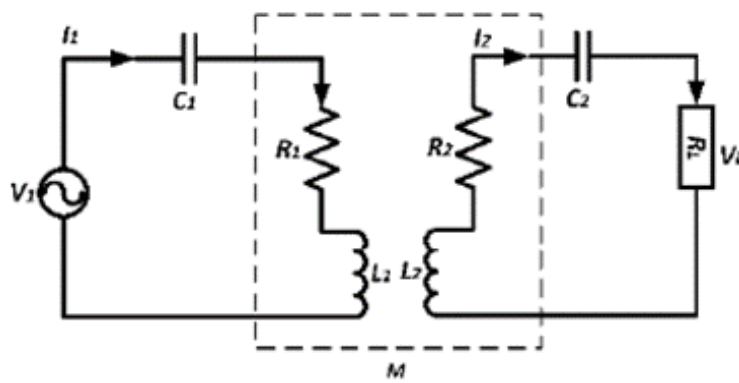

Fig. 2: Series-Series topology [8].

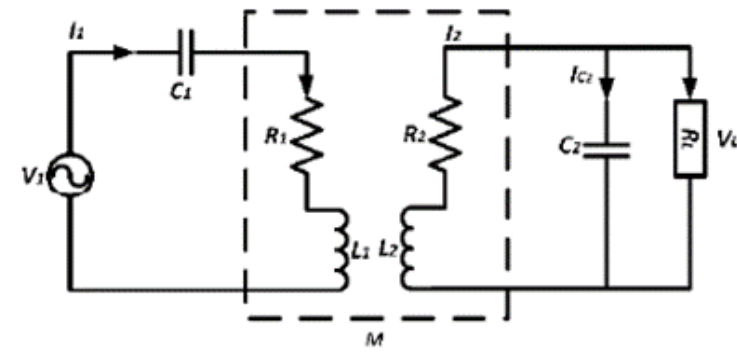

Fig. 3: Series-Parallel topology [8].

The model used for this article is an EV with a power consumption of $3.6 \mathrm{~kW}$ with 40 $\mathrm{kHz}$ resonant frequency $\left(\omega_{o}\right)$. The most common maximized output voltage is $168 \mathrm{~V}\left(V_{L}\right)$ for the testing of a rechargeable battery in an EV [23]. Therefore, the input voltage to recharge the EV's battery is $240 \mathrm{~V}$. As the output voltage and output power are already known ( $\mathrm{P}_{\mathrm{o}}$ equal to $\mathrm{P}_{\text {in) }}$. The other parameters can be calculated, as shown below:

The load resistance can be found using equation (1). A higher power delivery into the load with maximum power transfer capability and efficiency is improved by adding a compensation circuit at the secondary side, which is where the load is located [13].

$$
R_{L}=\frac{V_{L}^{2}}{P_{o}}
$$

The root means square (RMS) value for primary and secondary current can be found using equation (2) and (3). Note that the output power $\left(P_{o}\right)$ is equal to $\left(P_{\text {in }}\right)$ since the coil resistance is ignored. Meanwhile, the RMS value for the primary voltage is set to be $240 \mathrm{~V}$.

$$
\begin{aligned}
& I_{1, r m s}=\frac{P_{i n}}{V_{I, r m s}} \\
& I_{2, r m s}=\frac{V_{L, r m s}}{R_{L}}
\end{aligned}
$$

$L_{2}, M$ and $L_{1}$ are calculated using the equation below. The quality factor, $Q S$, and coupling coefficient, $k$, are set in the calculation as 4 and 0.2 . The reason for the coupling coefficient to be 0.2 is that it can avoid the bifurcation issue. Bifurcation is a phenomenon where there exists more than one angle frequency in resonance inductive power transfer. It happens due to an increase in the coupling coefficient to a certain value. Therefore, the value of $k$ should be addressed carefully to avoid a decrease in a voltage gain of the system [10]. It is noted 
that the coefficient of coupling is correlated with the distance between the coils. The inductance value will be affected if the value of the coupling coefficient is changed [14].

$$
\begin{aligned}
& L_{2}=\frac{Q_{S} R_{L}}{\omega_{o}} \\
& M=\frac{I_{2, r m s} R_{L}}{I_{1, r m s} \omega_{o}} \\
& L_{1}=\frac{M^{2}}{L_{2} k^{2}}
\end{aligned}
$$

$\omega_{o}$ is the resonant frequency, which is equal to $2 \pi f$. A compensation circuit placed at the primary side can make the resonant frequency, $\omega_{\mathrm{o}}$ be transferred equally to the operating frequency of the power source [13,15]. Using the value of the frequency, $L_{1}$ and $L_{2}$, primary capacitance, $C_{1}$, and secondary capacitance, $C_{2}$, can be known. Equation (7) is used to find $C_{1}$, whereas Eq. (8) is used for $C_{2}$.

$$
\begin{aligned}
& f_{1}=\frac{1}{2 \pi \sqrt{L_{1} C_{1}}} \\
& f_{2}=\frac{1}{2 \pi \sqrt{L_{2} C_{2}}}
\end{aligned}
$$

Power calculation can be calculated at both the primary and secondary sides using Eq. (9) below. $\mathrm{P}$ is the power of the primary/secondary side (W), V is the voltage at the primary/secondary side (V), and I is the current at the primary/secondary side (A). Table 1 lists the required parameters for the simulations.

$$
P=(V)(I)
$$

Table 1: Parameters used in wireless power transfer

\begin{tabular}{cc}
\hline Component & Parameter \\
\hline$V_{P}$ & Primary Voltage \\
$C_{P}$ & Primary Capacitance \\
$R_{P}$ & Primary Resistance \\
$L_{P}$ & Primary Inductance \\
$L_{S}$ & Secondary Inductance \\
$C_{S}$ & Secondary Capacitance \\
$R_{S}$ & Secondary Resistance \\
$R_{L}$ & Load Resistance \\
$Q$ & Quality Factor \\
$k$ & Coefficient of Coupling \\
\hline
\end{tabular}

Both compensation designs are usually used in the high-power industry, including WPT. SS-topology and SP-topology provide a constant current and constant voltage during the charging process making them suitable to be applied to EV [10]. The arrangement of the capacitance inside the circuit determines the compensation design used. The series arrangement of the capacitor at the primary side (Fig. 4a) makes it independent of the primary inductance as well as the load, making it suitable for dynamic applications. In contrast, the parallel arrangement of a capacitor is to increase the primary current of the 
circuit. At the secondary side, the series arrangement of capacitance (Fig. 4a) is able to stabilize the voltage supply to the load, while the capacitance arrangement in parallel (Fig. $4 b)$ able to supply stable current to the load $[10,15]$.

The compensation arrangement is not limited to only four arrangements, as already mentioned, but there is also a hybrid arrangement of capacitors and inductors [16]. The hybrid compensation circuits are LCC-LCC, LCL-LCL, LCC-P, LCL-P, S-CLC, LCL-S, CCL-S and multi-LCC (Fig. 5 in [17]). However, only SS- and SP-topologies will be further discussed in this article.

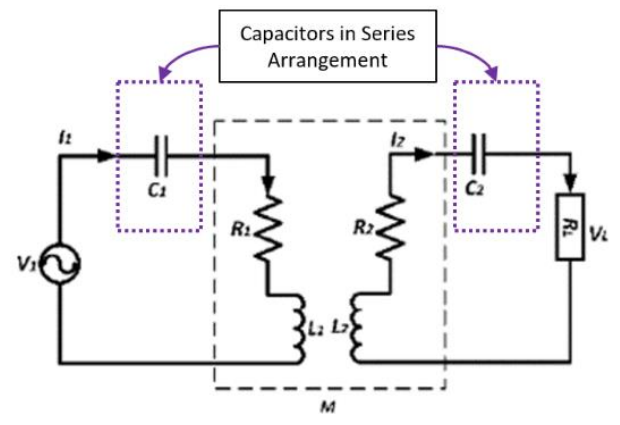

(a)

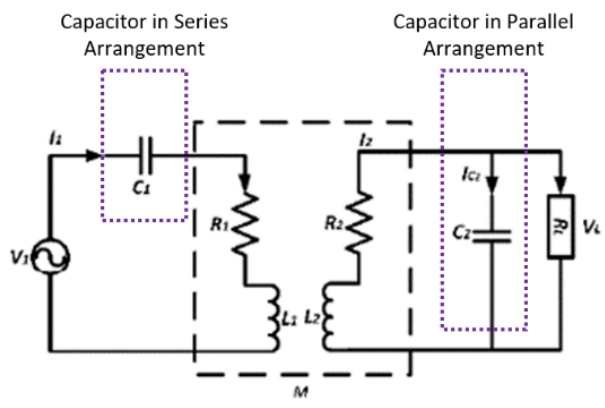

(b)

Fig. 4: (a) Series-Series arrangement, (b) Series-Parallel arrangement [8].

Despite that, it also depends on the type of load that is used in the system in order to maximize the capability of the compensation design applied to it. Taking into consideration the EV to work with DWC, SS-topology can be seen as a better application towards charging the EV's battery. The reason is that the coupling coefficient of the compensation design is less affected while the EV is in motion. Also, SS-topology is capable of operating at both constant rates of voltage and current output which makes it more reliable to be implemented for the EV [10]. On the other hand, SP-topology compensation emits higher power output and efficiency with higher loads, making it appropriate to be applied in EV due to its problem in travel distance because of its small built battery capacity $[13,15]$. Both SS and SP compensation designs display their advantages in implementation under DWC, but further analysis is required to find out which of the two compensations can perform under dynamic situations.

\section{RESULTS AND ANALYSIS}

SS-topology and SP-topology are constructed as in Fig. 5 and Fig. 6, in NI Multisim software. The letter $\mathrm{P}$ or $\mathrm{S}$ is the notation for primary or secondary in the circuit diagrams. Both compensation circuits were simulated under three variables. The variables that were manipulated were the resonant frequency, coefficient of coupling, and the resistance load. These variables are chosen based on dynamic situations that the EV may experience in the long run.

Under the ideal case, which there is zero resistance tolerance, SS-topology appeared to be better than SP-topology in terms of maximum output power and power transfer efficiency. The efficiency achieved by SS-topology was $99.94 \%$ while SP-topology struggled to transfer power wirelessly with $28.39 \%$ efficiency. 


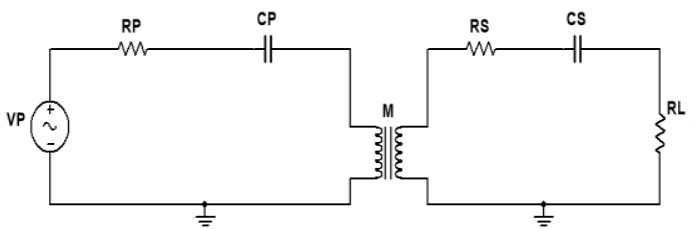

Fig. 5: SS-topology circuit diagram in NI Multisim.

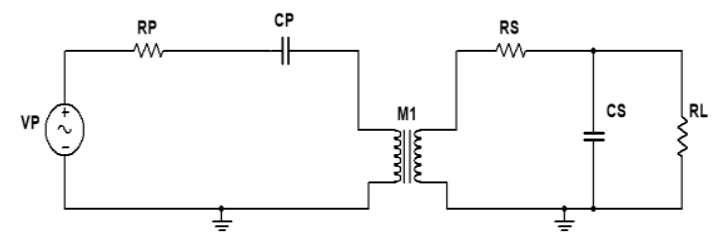

Fig. 6: SP-topology circuit diagram in NI Multisim.

Table 2: Calculated parameters for NI Multisim simulations

\begin{tabular}{cc}
\hline Parameter & Value \\
\hline$R_{L}$ & $7.84 \Omega$ \\
$L_{P}$ & $398 \mu \mathrm{H}$ \\
$L_{S}$ & $124.78 \mu \mathrm{H}$ \\
$M$ & $44.57 \mu \mathrm{H}$ \\
$C_{P}$ & $39.78 \mathrm{nF}$ \\
$C_{S}$ & $126.87 \mathrm{nF}$ \\
$K$ & 0.2 \\
$Q S$ & 4 \\
\hline
\end{tabular}

In order to analyse the performance between the two topologies, Fig. 7, Fig. 8, and Fig. 9 show the relationship for each variable with power transfer efficiency. The coupling coefficient changes accordingly, based on the distance as well as the alignment between the coils [20]. The value range tested is between 0.01 and 0.2 , in order to avoid the occurrence of the bifurcation issue. It is known that the coupling coefficient decreases with the increase of distance and vice-versa, as is the case with misalignment between the coils [21]. Referring to Fig. 7, from $0.06(41.3 \mathrm{~cm})$ to $0.2(25.9 \mathrm{~cm}), \mathrm{SS}$-topology is able to transmit better power efficiency from the transmitter coils to the receiver coils. On the other hand, at the distance of $36.8 \mathrm{~cm}$ between the coils with 0.08 coupling coefficient, SP-topology reaches its maximum potential with $96.47 \%$ of efficiency. When it comes to tolerance to coupling coefficient, SP-topology appears to be less suitable based on its performance compared to SS-topology. SS-topology is capable of maintaining more than $90 \%$ efficiency with bigger air-gap fluctuation approximately $\approx 16 \mathrm{~cm}$.

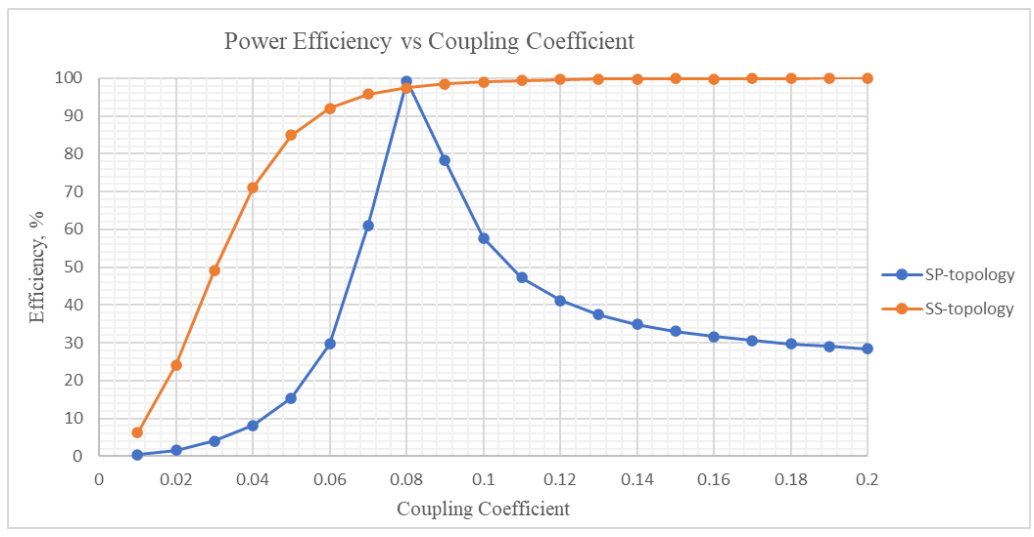

Fig. 7: SS and SP simulation for power efficiency, $\eta$ vs coupling coefficient, $k$.

Another simulation test conducted is the manipulation to the resonant frequency. Based on Fig. 8, both topologies show the fluctuation in power efficiency. The range of the 
resonant frequency for the simulation test is chosen between $30 \mathrm{kHz}$ and $50 \mathrm{kHz}$ because it is in the range of EV operational specifications for charging pad manufacturers. The frequency for inductive power transfer can range from $3 \mathrm{kHz}$ to $1 \mathrm{MHz}$ [20]. In terms of maintaining power efficiency, both topologies are unable to consistently maintain power transfer as the frequency is altered. In spite of the inconsistency, SS-topology expresses better efficiency within the frequency range of $38 \mathrm{kHz}$ until $42 \mathrm{kHz}$ while SP-topology has its highest peak with $56.4 \%$ of power transfer efficiency when the resonant frequency is 41 $\mathrm{kHz}$. Since the system is calculated and designed with a frequency value of $40 \mathrm{kHz}$, the outcome for the maximum power efficiency is technically closer to the assigned value of the resonant frequency. SP-topology experienced more significant power loss compared to SS-topology in this study. Hence, it can be observed that for any slight increase or decrease from the theoretical resonant frequency, the power efficiency will drop lower than the maximum power efficiency achieved. This proves that both topologies are sensitive when there is a deviation in resonant frequency [10].

The change in load resistance also affected the efficiency during the power transfer. Load resistances represent the battery capacity in EV. Bigger load signifies more power can be stored, thus requiring less charging time per day. Figure 9 illustrates the results of power efficiency for both topologies under alteration of the load resistance value. In this simulation test, when both topologies were paired to a bigger load (100 $\Omega$ ), SP-topology operated better than SS-topology with regards to efficiency in WPT. Contrarily, SS-topology attained $99.93 \%$ efficiency with a load value at $10 \Omega$.

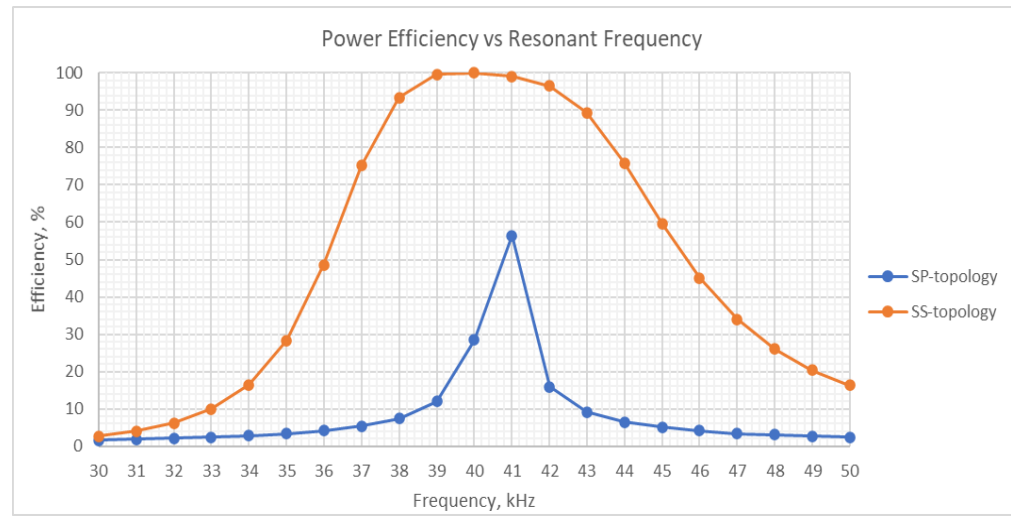

Fig. 8: SS and SP simulation for power efficiency, $\eta$ vs resonant frequency, wo.

Based on the traits analysed for DWC, the relationship between efficiency with resonant frequency, coupling coefficient and load resistance, SS-topology and SP-topology each have their respective strengths in wireless charging. For optimum real application of EV, the coupling coefficient, $k$ was kept at 0.2 to avoid any presence of more than one angle frequency during the resonance inductive power transfer. Because both topologies' efficiency easily affected by the resonant frequency, $\omega_{o}=41 \mathrm{kHz}$ was set as ideal operational frequency at the transmitter side. The same parameter values in Table 2 remain constant except for load resistance for each compensation design. Series design at the receiver side resulted in lower voltage but higher current. Parallel compensation at the secondary side made the voltage received to be high while the current received was low. Under the condition of $3.6 \mathrm{~kW}$ model, SS-topology had a longer transmission distance with a load of $R_{L}=8.1 \Omega$. As for SP-topology, the same output power was gained with $R_{L}=130 \Omega$. Table 3 represents the data simulated under those specifications with the expression of achieving $3.6 \mathrm{~kW}$ of power transmission. 


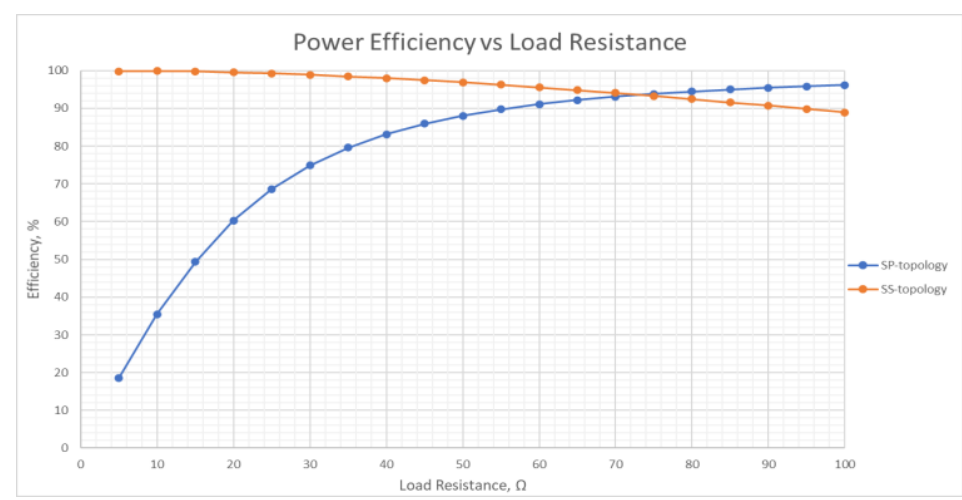

Fig. 9: SS and SP simulation for power efficiency, $\eta$ vs load resistance, $\Omega$.

Table 3: Compensation design $3.6 \mathrm{~kW}$ simulation paired with respective loads.

\begin{tabular}{ccc}
\hline & $\begin{array}{c}\text { Series-Series (SS) } \\
\text { compensation design }\end{array}$ & $\begin{array}{c}\text { Series-Parallel (SP) } \\
\text { compensation design }\end{array}$ \\
\hline Resistance load, $\boldsymbol{R}_{\boldsymbol{L}}$ & 8.1 & 130 \\
Primary voltage (rms) & $240 \mathrm{~V}$ & $240 \mathrm{~V}$ \\
Secondary voltage (rms) & $171 \mathrm{~V}$ & $683 \mathrm{~V}$ \\
Primary current (rms) & $15.20 \mathrm{~A}$ & $15.16 \mathrm{~A}$ \\
Secondary current (rms) & $21.10 \mathrm{~A}$ & $5.26 \mathrm{~A}$ \\
Power transmitted & $3648 \mathrm{~W}$ & $3640 \mathrm{~W}$ \\
Power received & $3608 \mathrm{~W}$ & $3592 \mathrm{~W}$ \\
Power efficiency, $\mathbf{n}$ & $98.9 \%$ & $98.6 \%$ \\
\hline
\end{tabular}

The main contribution is that both compensation designs have different features for WPT. SS-topology is fitted for small load systems, providing the compensation design of SS tolerance towards the change in frequency and airgap distance between coils. While SPtopology is very relevant for large load systems.

\section{CONCLUSION}

The two topologies have been simulated based on DWC features when EV is technically in a state of motion. The relationship for power efficiency with resonant frequency, coupling coefficient and load resistances is tested to identify the best fitted compensation design for steady power transfer from the charging pad to the battery. From the simulation results acquired, both designs react differently for each variable. Even using the same parameters, the maximum potential of DWC reflected on the load paired to the system. Great efficiency was achieved as SS-topology used small loads, in contrast to SPtopology which gained great efficiency with bigger loads. Nevertheless, through comparing and analysing the simulation data, SS-topology appeared ideal to implement for DWC. Despite the fact that it can only perform at utmost capability with small loads, it is important to highlight SS-topology's potential to maintain it tolerance towards deviation in resonant frequency and coupling coefficient. For practical applications, the ability to transfer power at a consistent rate without major power loss is an important choice criterion when the vehicle is moving [22]. SP-topology paired greatly with bigger loads. However, it is suitable for longer travel distances but requires more charging time because of the bigger loads. SPtopology seems more suitable for SWC due to its sensitivity towards changes in coupling 
coefficient. Not to mention, this article analysed the conditions for DWC which required an EV cruising while charging. For that reason, it touched on different application situations of two chosen compensation designs and elaborated on how to choose the ideal design suitable for practical applications.

\section{ACKNOWLEDGEMENT}

We would like to thank partial financial support by the International Islamic University Malaysia under the Kulliyyah of Engineering Postgraduate Tuition Fee Waiver Scheme 2019 (TFW2019) and also this work was partially supported by the Ministry of Higher Education Malaysia under the Fundamental Research Grant Scheme (Grant number FRGS19-067-0675).

\section{REFERENCES}

[1] Vepachedu S. (2017) The History of The Electric Car. Andhra Journal of Industrial News. 1427.

[2] Salah WA, Alsayid B, Albreem MAM, Abu Zneid B, Alkhasawneh M, Al Mofleh A, Abu Sneineh A, Al Aish AA. (2019) Electric vehicle technology impacts on energy. International Journal of Power Electronics and Drive Systems (IJPEDS).10.1.10.11591/ijpeds.v10.i1.pp19.

[3] Ma S, Jiang M, Tao P, Song C, Wu J, Wang J, Deng T, Shang W. (2018) Temperature effect and thermal impact in lithium-ion batteries: A review. Progress in Natural Science: Materials International, 28(6): 653-666. doi: 10.1016/j.pnsc.2018.11.002

[4] Lukic S, Pantic Z. (2013) Cutting the Cord: Static and dynamic inductive wireless charging of electric vehicles. IEEE Electrification Magazine, 1(1): 57-64. doi: 10.1109/MELE.2013.2273228

[5] Afridi K. (2018) Wireless charging of electric vehicles. National Academy of Engineering. in Frontiers of Engineering: Reports on Leading-Edge Engineering from the 2017 Symposium. Washington, DC: The National Academies Press. doi: 10.17226/24906.

[6] Li S, Mi CC. (2015) Wireless power transfer for electric vehicle applications. IEEE Journal of Emerging and Selected Topics in Power Electronics, 3(1): 4-17. doi:10.1109/JESTPE.2014.2319453

[7] Zaini SA, Yusoff SA, Abdullah AA, Khan S, Abd Rahman F, Nanda. NZ. (2020) Investigation of magnetic properties for different coil sizes of dynamic wireless charging pads for electric vehicles (EV). IIUM Engineering Journal, 21(1): 23-32. doi:10.31436/iiumej.v21i1.1108

[8] Mi C, Abdul Masrur M. (2017) Hybrid electric vehicles: Principles and applications with practical perspectives. John Wiley \& Sons.

[9] Ahmad A, Alam MS, Chabaan R. (2018) A comprehensive review of wireless charging technologies for electric vehicles. IEEE Transactions on Transportation Electrification, 4(1): 38-63. doi: 10.1109/TTE.2017.2771619

[10] Aditya K, Williamson SS. (2014) Comparative study of series-series and series-parallel compensation topologies for electric vehicle charging. IEEE 23rd International Symposium on Industrial Electronics (ISIE). doi: 10.1109/ISIE.2014.6864651

[11] Shevchenko V, Husev O, Strzelecki R, Pakhaliuk B, Poliakov N, Strzelecka N. (2019) Compensation topologies in IPT systems: Standards, Requirements, Classification, Analysis, Comparison and Application. IEEE Access, 7, 120559-120580. doi: 10.1109/ACCESS.2019.2937891

[12] Azambuja R, Brusamarello VJ, Haffner S, Porto RW. (2017) Full four capacitor circuit compensation for inductive power transfer. Conference Record - IEEE Instrumentation and Measurement Technology Conference, 2-7. doi: 10.1109/I2MTC.2013.6555406.

[13] Chenggang F, Jiancheng S, Lingyan L, Yameng W. (2017) Practical considerations of seriesseries and series-parallel compensation topologies in wireless power transfer system 
application. 2017 IEEE PELS Workshop on Emerging Technologies: Wireless Power Transfer (WoW), ID 41321671. doi: 10.1109/WoW.2017.7959404

[14] Rehman, M., Baharudin, Z., Nallagownden, P., \& Islam, B. (2017). Modeling and Analysis of Series-Series and Series-Parallel Combined Topology for Wireless Power Transfer using Multiple Coupling Coefficients. IJCSNS International Journal of Computer Science and Network Security, VOL.17 No.11, November 2017.

[15] Rituraj G, Joy ER, Kushwaha BK, Kumar P. (2014) Analysis and comparison of series-series and series-parallel topology of contactless power transfer systems. TENCON 2014-2014 IEEE Region 10 Conference. doi: 10.1109/TENCON.2014.7022440.

[16] Nanda, N. N., Yusoff, S. H., Toha, S. F., Hasbullah, N. F., \& Roszaidie, A. S. A Brief Review: Basic Coil Designs for Inductive Power Transfer. Indonesian Journal of Electrical Engineering and Computer Science (IJEECS), Vol. 20, No. 3, December 2020, pp. 17031716. doi: 0.11591/ijeecs.v20.i3.pp1703-1716.

[17] Abou Houran M, Yang X, Chen W. (2018) Magnetically coupled resonance WPT: Review of compensation topologies, resonator structures with misalignment, and EMI diagnostics. Electronics, 11: 296. doi:10.3390/electronics7110296

[18] Barman SD, Reza AW, Kumar N. (2014). Efficiency maximization of resonant coupled wireless power transfer system via impedance matching based on coupling tuning. $3^{\text {rd }}$ International Conference on Computer Engineering \& Mathematical Sciences, Langkawi, Malaysia, November 2014.

[19] El-Shahat A, Ayisire E, Wu Y, Rahman M, Nelms D. (2019). Electric vehicles wireless power transfer state-of-the-art. Energy Procedia, 162: 24-37. doi: 10.1016/j.egypro.2019.04.004

[20] Panchal C, Stegen S, Lu J. (2018) Review of static and dynamic wireless electric vehicle charging system. Engineering Science and Technology, an International Journal, 21(5): $922-$ 937. doi: 10.1016/j.jestch.2018.06.015

[21] Al-Saadi M, Al-Gizi AG, Al-Chlaihawi S, Al-Omari AH. (2018). Inductive power transfer for charging the electric vehicle batteries. Electrotehnică, Electronică, Automatică, 66: 29-39.

[22] Carmeli MS, Castclli-Dezza F, Mauri M, Rossi M, Dolata A, Pedretti M, Simonini I. (2018) Analysis of a quasi-dynamic wireless power transfer system for EV batteries charging. 2018 International Symposium on Power Electronics, Electrical Drives, Automation and Motion (SPEEDAM), 383-388. doi: 10.1109/SPEEDAM.2018.8445238

[23] Aditya K. (2016) Design and implementation of an inductive power transfer system for wireless charging of future electric transportation. $\mathrm{PhD}$ thesis. Electrical, Computer and Software Engineering Department, University of Ontario Institute of Technology Oshawa, Ontario, Canada. 